\title{
Is There Any Correlation Between Normal Blood Pressure Level and Cynophobia?
}

\author{
Muhammad Imran Qadir, Mujahid Hussain* and Mubashir Ali \\ Institute of Molecular Biology and Biotechnology, Pakistan \\ *Corresponding author: Mujahid Hussain, Institute of Molecular Biology and Biotechnology, Pakistan
}

ARTICLE INFO

Received: 㓞 February 19, 2019

Published: March 05, 2019

Citation: Muhammad Imran Qadir Mujahid Hussain, Mubashir Ali. Is There Any Correlation Between Normal Blood Pressure Level and Cynophobia?. Biomed J Sci \& Tech Res 15(3)-2019. BJSTR. MS.ID.002708.

\begin{abstract}
Blood pressure, "pressure of circulating blood on blood vessels". Normal value for higher systolic blood pressure (maximum during one heart beat) is $120 \mathrm{mmHg}$ or $16 \mathrm{Kpa}$ while normal value for lower diastolic blood pressure (minimum during one heart beat) is $80 \mathrm{mmHg}$ or $11 \mathrm{Kpa}$. Increase than normal value causes hypertension leading towards serious diseases while decrease than normal value causes hypotension also leads toward serious problem. Dog that is domestic as well as wild animal, some people kept them at their houses, love them and some people get affraid from the dogs which is called cynophobia. During this study, any relation between blood pressure and cynophobia was found by measuring blood pressure of participants and the participants were asked to answer the question "either they get afffraid from the dog or not?" After this, stastical analysis by using Microsoft exwel, T-test was performed and it was found that,
\end{abstract}

There is no correlation between normal blood pressure and cynophobia.

Keywords: Blood Pressure; Cynophobia; Correlation; P-Value; Participants; Dog Phobia; Visualization; Molecular Graphics; Structural Molecular Biology; Molecular Modeling

\section{Introduction}

Blood pressure, "pressure of circulating blood on blood vessels" is called blood pressure. Blood pressure directly represents heart beat or heart pumping. There are two types of blood pressure, one is called systolic (Maximum during one heart beat) and other is called diastolic (Minimum during one heart beat). Blood pressure is directly corelated with respiratory track, heart rate, oxygen saturation and blood temperature. It is measured in millimeters of mercury (mmHg) or kilopascal (Kpa) [1]. Normal blood pressure level for both systolic and diastolic are $120 \mathrm{mmHg}(16 \mathrm{Kpa})$ and $80 \mathrm{mmHg}(11 \mathrm{Kpa})$ respectively, and these values change with age. Higher or lower value than normal value creates problem i.e. Higher value is called Hypertension while lower value is called Hypotension. Hypertension leads to diseases like stroke, heart diseases, kidney failure while Hypotension leads toward cardiovascular diseases. It is worldwide spread disease, almost one billion people affected by it and 9.4 million death occur every year by it. Dog is considered as both domestic as well as wild animal [2-4]. It belongs to the family of Mammilia and many researches prove that dog evolves from Wolves. Many people love the dogs and kept them at their houses for the purpose of security while many people get affraid from the dogs that is called dog phobia or cynophobia. This is the problem that is faced by both parents and children. Somehow it is genetically transmitted problem and environmental factors also effect on it. (Ollendick, 1988) [5]. Its effects children activities that are recreational King et al. We performed this experiment to find any relation between Blood pressure and dog phobia.

\section{Materials and Methods}

\section{Project Design}

We prepared a question are. In the question are, participants were asked "either they get affraid from the dogs or not?" 200 students of Institute of Pure and Applied Biology, Bahhuadin Zakariya University, Multan, Pakistan participated in the study [6].

\section{Measurement of Blood Pressure}

Blood pressure of participants was measured by using instrument called Sphygmomanometer. It was modern instrument having sensor and automatically showed the values in numerical forms [7]. Higher value was considered as systolic blood pressure while lower value was considered as diastolic blood pressure.

\section{Statistical Analysis}

For result analysis, we used M-Stat software. After M-Stat software, t-test was conducted. significant value $\mathrm{p}<0.05$ was assumed. 


\section{Results and Discussion}

Relation of blood pressure (Mean \pm SD) with dog phobia is shown in table1. Normal systolic blood pressure that showed cynophobia was $118.76 \pm 15.49$ while systolic blood pressure that did not show cynophobia was $121.25 \pm 13.76$. Normal diastolic blood pressure that showed cynophobia was $78.05 \pm 54.04$ while diastolic blood pressure that did not show cynophobia was $74 \pm 9.69$. The normal value for both systolic and diastolic blood pressure that showed cynophobia was $98.41 \pm 44.62$ while for both systolic and diastolic blood pressure that did not show cynophobia was $97.37 \pm 97.14$ (Table 1). According to Ollendick 1988, that dog phobia is affected by genetic and environmental factors, but it was found that there is no correlation between normal blood pressure and cynophobia because $p$-value for systolic, diastolic and both was $0.29,0.38$ and 0.79 respectively and this was greater than the considered significant value [8]. There was no correlation found between normal blood pressure and cynophobia.

Table 1: Relation between blood pressure (Mean \pm SD) and dog phobia. Non-significant ( $\mathrm{p}>0.05)$.

\begin{tabular}{|c|c|c|c|}
\hline $\begin{array}{c}\text { Blood Pressure } \\
\text { Type }\end{array}$ & Cynophobia & $\begin{array}{c}\text { Non- } \\
\text { Cynophobia }\end{array}$ & P-Value \\
\hline Systolic & $118.76 \pm 15.49$ & $121.25 \pm 13.76$ & 0.296913 \\
\hline Diastolic & $78.05 \pm 54.04$ & $74 \pm 9.69$ & 0.380144 \\
\hline Both & $98.41 \pm 44.62$ & $97.37 \pm 97.14$ & 0.795374 \\
\hline
\end{tabular}

\section{ISSN: 2574-1241}

DOI: 10.26717/BJSTR.2019.15.002708

Mujahid Hussain. Biomed J Sci \& Tech Res (C) (P) This work is licensed under Creative

Submission Link: https://biomedres.us/submit-manuscript.php

\section{References}

1. Ettehad D, Emdin CA, Kiran A, Anderson SG, Callender T, et al. (2016) Blood pressure lowering for prevention of cardiovascular disease and death: a systematic review and meta-analysis. The Lancet 387(10022): 957-967.

2. (2017) American Heart Association. What is high blood pressure? South Carolina State Documents Depository.

3. Williamson JD, Supiano MA, Applegate WB, Berlowitz DR, Campbell $\mathrm{RC}$, et al. (2016) Intensive vs standard blood pressure control and cardiovascular disease outcomes in adults aged $\geq 75$ years: a randomized clinical trial. Jama 315(24): 2673-2682.

4. Fatjó J, Darder P, Calvo P, Bowen J, Bulbena A, et al. (2016) Is dog ownership the same for men and women, parents and non-parents? Journal of Veterinary Behavior: Clinical Applications and Research 8(4): e44.

5. Sherry M, Thomas P, Chui WH (2010) International students: A vulnerable student population. Higher education 60(1): 33-46.

6. O Farrell V (1997) Owner attitudes and dog behavior problems. Applied Animal Behavior Science 52(3-4): 205-213.

7. O FARRELL VA. 1-1 Effects of owner personality and 1 attitudes on dog behavior. The domestic dog: its evolution behavior and interactions with people.

8. Bruehl S, Carlson CR (1992) McCubbin JA. The relationship between pain sensitivity and blood pressure in normotensives. Pain 48(3): 463-467.

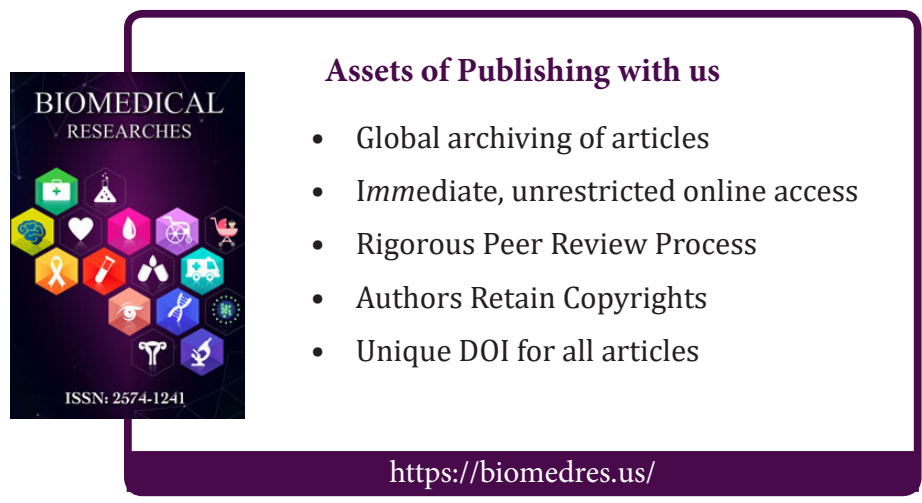

